\title{
Bending Creep Behavior of Hornbeam Wood
}

\section{Puzanje drva graba pri savijanju}

\author{
Original scientific paper • Izvorni znanstveni rad \\ Received-prispjelo: 10. 2. 2016. \\ Accepted-prihvaćeno: 6.9 .2016$. \\ UDK: $630 * 812.71 ; 630 * 812.77 ; 674.031 .632 .122$ \\ doi:10.5552/drind.2016.1609
}

\begin{abstract}
This study examined the effect of altitude on bending creep behavior of hornbeam lumber (Carpinus betuluse). For this purpose, 9 hornbeam trees from three different altitudes (400, 800 and $1100 \mathrm{~m})$ in the northern forests of Iran were selected. Clear samples were cut from mature wood in diameter at breast height (DBH). 108 prepared samples (dimensions: $2.5_{\times} 2.5 \times 41 \mathrm{~cm}$ ) were conditioned at room temperature of $20{ }^{\circ} \mathrm{C}$ and two relative humidities $(R H)$ of $65 \%$ and $95 \%$. First, the maximum bending load was determined by three-point static bending tests in acclimatized room and then flexural creep parameters, such as relative creep, creep modulus and creep factor, at $20 \%$ of the maximum bending load, were calculated. Results indicated that at $65 \%$ RH, the effect of altitude on creep parameters was significant. The maximum values of relative creep and creep factor were observed at the altitude of $800 \mathrm{~m}$, and the minimum values at the altitude of $400 \mathrm{~m}$. The maximum values of creep modulus were observed at the altitude of $400 \mathrm{~m}$ and the minimum values at the altitude of $800 \mathrm{~m}$. Also, at $95 \%$ $R H$, the effect of altitude on creep modulus was significant but it was not significant on relative creep and creep factor. The maximum creep modulus was observed at the altitude of 400 and the minimum at the altitude of $800 \mathrm{~m}$.
\end{abstract}

Keywords: altitude, Carpinus betuluse, creep factor, creep modulus, relative creep, relative humidity

SAŽETAK・U radu su prikazani rezultati istraživanja utjecaja nadmorske visine staništa stabala na puzanje drva graba (Carpinus betuluse) pri savijanju. Za istraživanje je odabrano devet stabala graba iz šuma na sjeveru Irana, i to na tri različite lokacije - nanadmorskoj visini 400, 800 i $1100 \mathrm{~m}$. Uzeti su čisti uzorci zrelog drva na visini prsnog promjera (DBH). Ukupno 108 pripremljenih uzoraka (dimenzija 2,5 × 2,5 $\times 41 \mathrm{~cm}$ ) kondicionirano je pri sobnoj temperaturi od $20{ }^{\circ} \mathrm{C}$ i uz dvije relativne vlažnosti zraka (RH), 65 i $95 \%$. Najprije je napravljen statički test savijanja u tri točke te određeno maksimalno opterećenje (čvrstoća na savijanje) u aklimatiziranoj prostoriji. Potom su izračunani parametri puzanja pri savijanju kao što su relativno puzanje, modul puzanja i faktor puzanja u području $20 \%$ maksimalnog opterećenja savijanja. Rezultati istraživanja na uzorcima kondicioniranim pri $65 \%$ relativne vlažnosti zraka pokazali su da je utjecaj nadmorske visine na parametre puzanja bio značajan. Maksimalne vrijednosti relativnog puzanja i faktora puzanja zabilježene su za uzorke s nadmorske visine $800 \mathrm{~m}$, a minimalne vrijednosti za uzorke s nadmorske visine $400 \mathrm{~m}$. Maksimalne vrijednosti modula puzanja zabilježene su za uzorske drva s nadmorske visine $400 \mathrm{~m}$, a minimalne za one s nadmorske visine $800 \mathrm{~m}$. Također, na uzorcima kondicioniranim pri $95 \%$ relativne vlažnosti zraka utjecaj nadmorske visine na modul puzanja bio je značajan, ali se taj utjecaj nije pokazao značajnim za parametre relativnog puzanja i faktora puzanja. Najveći modul puzanja zabilježen je na uzorcima s nadmorske visine 400 m, a najmanji na uzorcima s nadmorske visine $800 \mathrm{~m}$.

Ključne riječi: nadmorska visina, Carpinus betuluse, faktor puzanja, modul puzanja, relativno puzanje, relativna vlažnost zraka

\footnotetext{
${ }^{1}$ Authors are Ph.D. student, associate professor, assistant professor and assistant professor at Islamic Azad University, Department of Wood and Paper Science and Technology, Science and Research Branch, Tehran, Iran. ${ }^{2}$ Author is associate professor at Islamic Azad University, Department of Wood and Paper Science and Technology, Chalous Branch, Chalous, Iran.

${ }^{1}$ Autori su doktorand, izvanredni profesor, docent i docent Sveučilišta Islamic Azad, Zavod za znanost o drvu i papiru i drvnu tehnologiju, Odjel za znanost i istraživanja, Tehran, Iran. ${ }^{2}$ Autor je izvanredni profesor Sveučilišta Islamic Azad, Zavod za znanost o drvu i papiru i drvnu tehnologiju, Odjel u Chalousu, Chalous, Iran.
} 


\section{INTRODUCTION}

\section{UVOD}

In most developing countries, demand for raw materials has been increasing in recent years. Considering the limited resources, especially in natural resources sector, the supply of needed raw material of wood for industry has been one of the most important problems in recent decades. Attention should be focused on the improvement of wood specifications and modification of some properties of wood, so as to provide better consumption of wood.

One of the most important characteristics affecting wood products is their time-dependent behavior. Generally, time dependent deformation of a material under sustained load is referred to as creep. If the load is large and the duration is long, failure will occur. Creep is one of the principal characteristics of wood resulting in poor performance in certain applications. It is essential to consider creep and creep rupture (load duration behavior) if wood is to be subjected to short and long-term loads. Wood has been characterized as viscoelastic material governed by creep behavior (Fridley, 1992a; Fridley, 1992b). Creep of these materials occurs as a result of a combination of elastic deformation and viscous flow, commonly known as viscoelastic deformation (Bodig and Jayne, 1993). The creep behavior of wood depends on a variety of factors including stress level, composite formulation, temperature, and last but not least, moisture content (Liu, 1993; Chen and Lin, 1997; Christopher et al., 2004; Zhang et al., 2007). High temperature and changes of humidity make wood prone to creep and can lead to problems of lowered resistance and capability of use (Van der put, 1989). When wood is exposed to moisture changes, the resulting deformation is higher than when wood is exposed to environmental conditions for the same time (Bazant and Meiri, 1985; Nakano, 1999). Simultaneous effect of the load and changes of wood moisture is called mechanical absorption effect (Kaboorani et al., 2013). This effect is very important in the use of wood for construction and causes failure and deformation in wooden beam (Kaboorani and Blanchet, 2014). The creep caused by mechanical absorption has been reported in different articles (Armstrong and Christensen, 1960, 1962; Armstrong and Kingston, 1962; Armstrong, 1972; Kowalski and Kowal, 1998; Hanhijarvi and Hunt, 1998).

Hornbeam, a diffuse-porous hardwood, covers about $33 \%$ of forests in northern Iran. The wood of this tree species is semi-hard to hard with high shrinkage and swelling, and working with it is hard (Kiaei, 2012). Considering the extent of this species and necessity of its right use, it must be given more attention. Therefore, the aim of this research is to: a) evaluate the effect of altitude on the flexural creep behavior of hornbeam wood (Carpinus betulus L.) harvested from Nowshahr Mashelek site, b) examine the relationship between physical and biometrical properties and displacement.

\section{MATERIALS AND METHODS 2. MATERIJALI I METODE}

Three hornbeam trees, of almost the same age of about 30 years, were chosen from three altitudes (400, 800 and $1100 \mathrm{~m}$ ). Nine logs (diameter: 25 and length: $70 \mathrm{~cm}$ ) at DBH were cut. Environmental characteristics, climate conditions habitat and specification of trees are presented in Table 1.

\subsection{Preparing the samples}

\subsection{Priprema uzoraka}

Sawn logs were stored in covered storage and environmental conditions. At first, logs were cut to 45 boards with $3.2 \mathrm{~cm}$ thicknesses from mature wood section (from ring 18 onwards, Makhmalbaf et al., 2007), then they were kept in environmental conditions for a period of two weeks. 108 final samples (dimensions: $2.5 \times 2.5 \times 41 \mathrm{~cm}$ ) were prepared (54 samples for creep test and 54 samples for bending test). Samples were placed in an acclimatized room $(65 \%$ and $95 \% \mathrm{RH}$, temperature of $20 \pm 3{ }^{\circ} \mathrm{C}$ ) for at least 3 weeks. All tests were done in the same conditions.

\subsection{Physical and biometrical properties \\ 2.2. Fizikalna i biometrijska svojstva}

Oven-dried density and basic density were measured according to ISO $3131(2.5 \times 2 \times 2 \mathrm{~cm})$. The weight and size of samples were measured in the water (soaking for 48 hours) and then in the oven (24 hours).

Franklin's method (1946) was used for separating fibers. In this method, a 50/50 \% ratio of acetic acid and hydrogen peroxide was used. First, the sample wood picks were placed inside a microquant, then the prepared acetic acid and hydrogen peroxide were poured on the wood samples by a calibrated pipette and the microquant was placed in an oven and heated for 48 $\mathrm{h}$ at $64{ }^{\circ} \mathrm{C}$. After whitening, the samples from the microquant were washed 4 to 5 times by a calibrated pipette with distilled water until the odor of hydrogen

Table 1 Characteristics of study sites and trees

Tablica 1. Obilježja staništa i stabala uključenih u istraživanje

\begin{tabular}{|c|c|c|c|c|c|}
\hline \multirow{1}{*}{$\begin{array}{c}\text { Site } \\
\text { Lokacija }\end{array}$} & $\begin{array}{c}\text { Elevation } \\
\text { Nadmorska visina } \\
\mathrm{m}\end{array}$ & $\begin{array}{c}\text { Annual } \\
\text { temperature } \\
\text { Prosječna godišnja } \\
\text { temperatura } \\
{ }^{\circ} \mathrm{C}\end{array}$ & $\begin{array}{c}\text { Annual } \\
\text { rainfall } \\
\text { Godišnje padaline } \\
\mathrm{mm}\end{array}$ & $\begin{array}{c}\text { Tree } \\
\text { Visina stabla } \\
\mathrm{m}\end{array}$ & $\begin{array}{c}\text { Triameter } \\
\text { Promjer stabla } \\
\mathrm{cm}\end{array}$ \\
\hline $\begin{array}{l}\text { Mashelak } \\
\text { forest-Nowshahr }\end{array}$ & 400 & 13.5 & 1345 & 17.6 & 17.3 \\
\cline { 2 - 6 } & 800 & 11.5 & 1300 & 29 \\
\hline
\end{tabular}


peroxide and acetic acid was completely removed. Fiber dimensions were measured by optic microscope (Nikon microscopic, Eclipse 50i, for the fiber length of $10 \mathrm{x}$ and for fiber diameter, cell wall thickness and lumen diameter of 40x).

\subsection{Bending properties}

\subsection{Svojstva drva pri savijanju}

In order to determine the maximum bending load, three-point static bending tests were carried out in accordance with ASTM D 143-94 (2000). Three replicates of each sample were tested using a computer-controlled INSTRON (Model Universal PT 20L) machine. The speed of the crosshead was set at 1.3 $\mathrm{mm} / \mathrm{min}$. Data were collected and used to calculate the modulus of elasticity (MOE) and short-term strength (modulus of rupture or MOR).

\subsection{Creep properties}

\subsection{Svojstva puzanja drva}

Using flexural creep equipment, creep tests were performed in accordance with ASTM D 6815-09. The immediate displacement, maximum displacement and permanent displacement at the mid-span of samples were measured by an extensometer during creep and recovery time. Total time to complete every test was one overnight (14 hours creep and 10 hours recovery). The stress was at $20 \%$ of the maximum bending load and was constant throughout the test. Based on measuring indications, creep factor, relative creep and creep modulus were calculated in accordance with equations 1,2 and 3.

Immediate displacement is the range of displacement in one minute after loading; the maximum displacement is the range of displacement in 840 minutes after loading; immediate return is the range of returned displacement in one minute after removing the load; and permanent displacement is the range of remaining displacement in 600 minutes after removing the load (return).

$$
\begin{gathered}
K_{t}=\frac{J_{t}}{J_{0}} \\
R_{c}=\frac{j_{t}-J_{0}}{J_{0}} \cdot 100 \\
E_{c}=\frac{L^{3} \cdot F}{4 \cdot b \cdot h^{3} \cdot J_{t}}
\end{gathered}
$$

Where $K_{t}$, is creep factor; $R_{c}$, is relative creep in percentage; $E_{c}$, is creep modulus in $\mathrm{MPa}, J_{t}$, is displacement in time of $t$ in $\mathrm{mm} ; J_{o}$, is displacement in one minute after loading; $L$, is length loading span in $\mathrm{mm} ; F$, is in Newton; $b$, is width of sample in $\mathrm{mm}$ and $h$, is thickness of sample in $\mathrm{mm}$.

\subsection{Parabolic equations}

\subsection{Parabolične jednadžbe}

To predict creep behavior, researchers depend on good judgment supported by available models. A number of empirical and theoretical methods have been developed to express time-dependent creep strains. Various researchers have investigated modeling of viscoelastic materials. Response linear and non-linear viscoelastic materials have been documented and a number of equations have been presented (Bodig and Jayne, 1993). The creep model, used in our research, is the power law proposed by Findley et al. (Findley et al., 1989; Kobbe, 2005). This model is simple and has been proven to apply to viscoelastic materials loaded at moderate levels. The general form of model is given as:

$$
\mu_{1}=\mu_{0}+a \cdot t^{m}
$$

Where $\mu_{1}$ is the time dependent creep strain, $\mu_{0}$ is the instantaneous strain, $a$ is the coefficient of timedependent strain, $t$ is the time after loading and $m$ is the exponential material constant. The analysis of the creep behavior of wood was performed based on the Findley et. al power law, adjusting the experimental values to the equation:

$$
\log \left(\mu_{1}-\mu_{0}\right)=\log a+m \log t
$$

The data were plotted as $\log \left(\mu_{1}-\mu_{0}\right)$ against $\log t$, where $m$ and $a$ were obtained from the regression line.

\section{RESULTS AND DISCUSSION 3. REZULTATI I RASPRAVA}

\subsection{Physical and biometrical properties}

3.1. Fizikalna i biometrijska svojstva

Analysis of variance (ANOVA) results indicated that the effect of altitude on fiber length, basic density and oven dried density was significant, but it was not significant on cell wall thickness, lumen diameter and fiber diameter (Table 2). Duncan's test included the value of fiber length related to the altitudes of 400 and $1100 \mathrm{~m}$ in one group and the value related to the alti-

Table 2 Average results of physical and biometric properties of hornbeam wood at different altitudes

Tablica 2. Prosječni rezultati fizikalnih i biometrijskih svojstava drva graba sa staništa na različitim nadmorskim visinama

\begin{tabular}{|c|c|c|c|c|c|c|}
\hline $\begin{array}{c}\text { Altitude } \\
\text { Nadmorska } \\
\text { visina } \\
\mathrm{m}\end{array}$ & $\begin{array}{c}\text { Cell wall } \\
\text { thickness } \\
\text { Debljina } \\
\text { stanične stijenke } \\
\mu \mathrm{m}\end{array}$ & $\begin{array}{c}\text { Lumen } \\
\text { diameter } \\
\text { Promjer } \\
\text { lumena } \\
\mu \mathrm{m}\end{array}$ & $\begin{array}{c}\text { Fiber } \\
\text { diameter } \\
\text { Promjer } \\
\text { vlakanaca } \\
\mu \mathrm{m}\end{array}$ & $\begin{array}{c}\text { Fiber } \\
\text { length } \\
\text { Duljina } \\
\text { vlakanaca } \\
\mu \mathrm{m}\end{array}$ & $\begin{array}{c}\text { Basic } \\
\text { Density } \\
\text { Osnovna gustoća } \\
\mathrm{kg} / \mathrm{m}^{3}\end{array}$ & $\begin{array}{c}\text { Dry } \\
\text { density } \\
\text { Gustoća suhog } \\
\text { drva } \\
\mathrm{kg} / \mathrm{m}^{3}\end{array}$ \\
\hline 400 & 5.16 & 12.22 & 22.55 & $1341.41^{\mathrm{b}}$ & $627.85^{\mathrm{b}}$ & $720.89^{\mathrm{c}}$ \\
\hline 800 & 4.94 & 13.64 & 23.54 & $1212.97^{\mathrm{a}}$ & $549.46^{\mathrm{a}}$ & $628.09^{\mathrm{a}}$ \\
\hline 1100 & 5.05 & 12.82 & 22.92 & $1370.06^{\mathrm{b}}$ & $587.36^{\mathrm{a}}$ & $679.06^{\mathrm{b}}$ \\
\hline $\mathrm{F}$ & $0.476^{\mathrm{ns}}$ & $2.667^{\mathrm{ns}}$ & $2.538^{\mathrm{ns}}$ & $10.416^{* *}$ & $3.424^{*}$ & $48.972^{* *}$ \\
\hline
\end{tabular}

** - Significant at $1 \%$ level / signifikantno na razini $1 \%$; - Significant at $5 \%$ level / signifikantno na razini $5 \%$; ns - not significant / nije signifikantno 

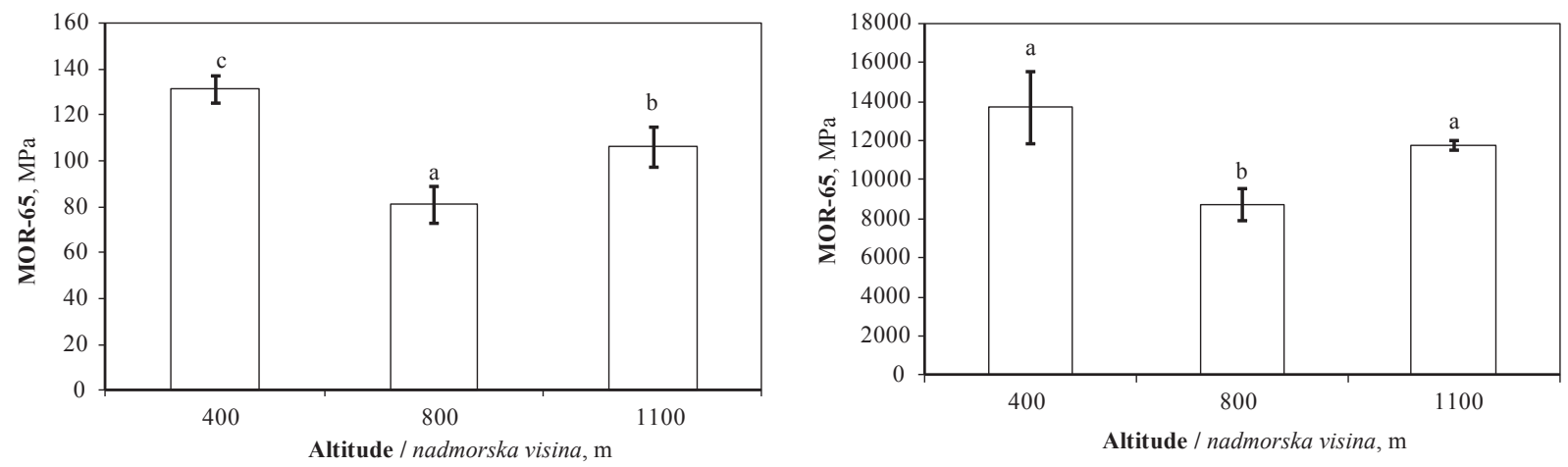

Figure 1 Hornbeam wood bending properties at three altitudes ( $65 \% \mathrm{RH})$

Slika 1. Svojstva drva graba pri savijanju za uzorke s tri nadmorske visine $(65 \% \mathrm{RH})$

tude of $800 \mathrm{~m}$ in another group. For basic density, Duncan's test also included the value of fiber length related to the altitudes of 800 and $1100 \mathrm{~m}$ in one group and the value related to the altitude of $400 \mathrm{~m}$ in another group. For oven dried density, however, these values were divided into three separate groups. The maximum average oven dried density, basic density and cell wall thickness were observed at the altitude of $400 \mathrm{~m}$, maximum fiber diameter and lumen diameter were observed at the altitude of $800 \mathrm{~m}$ and, finally, the maximum fiber length was observed at the altitude of 1100 $\mathrm{m}$. Different factors such as site, cell wall thickness and early wood/late wood ratio affect density of wood (Zobel and Van Buijtenen, 1989; Zobel and Sprague, 1998; Koubaa et al., 2000; Koga and Zhang, 2002; Zhu et al., 2008). The increase of density at the altitude of $400 \mathrm{~m}$ is due to higher cell wall thickness $(5.16 \mu \mathrm{m})$ and lower lumen diameter $(12.22 \mu \mathrm{m})$, which are comparable with the results of Kiaei (2013).

\subsection{MOE and MOR}

\subsection{MOE i MOR}

At $65 \% \mathrm{RH}$, ANOVA results indicated that the effect of altitude on MOR and MOE was significant. The maximum and minimum average MOR and MOE were found at the altitude of 400 and $800 \mathrm{~m}$, respectively. Duncan's test considered the value of MOE at altitudes of 400 and $1100 \mathrm{~m}$ in one group and at the altitude of $800 \mathrm{~m}$ in another group. However, the results of MOR were divided into 3 separate groups (a, b, c) (Fig.1).

At $95 \% \mathrm{RH}$, ANOVA results indicated that the effect of altitude on MOR and MOE was significant. The maximum and minimum MOR and MOE were ob-

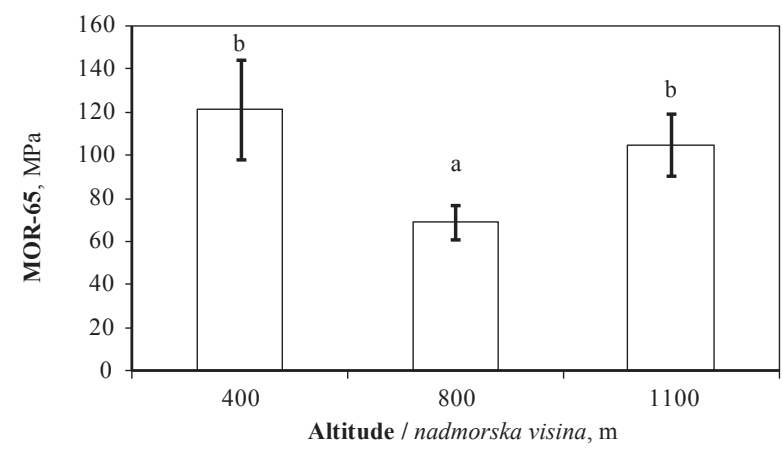

served at the altitude of 400 and $800 \mathrm{~m}$, respectively. Duncan's test included the value of MOR and MOE in two classes of altitude - 400 and $1100 \mathrm{~m}$ in one group (b) and $800 \mathrm{~m}$ in another group (a) (Fig. 2).

At $65 \%$ and $95 \% \mathrm{RH}$, the increase of MOE and MOR at the altitude of $400 \mathrm{~m}$ is due to the increase of wood density. As well known, there is a direct correlation between density and mechanical properties of wood (Zhang and Zhong, 1990; Zhang, 1997; Treacy et al., 2000; Charifo Ali, 2011). Also, average MOE and MOR is higher at $65 \% \mathrm{RH}$ than at $95 \% \mathrm{RH}$, which is compatible with the results of Kaboorani et al., (2013) and Ishmaru et al. (2001).

\subsection{Creep / Recovery behavior}

3.3. Puzanje / povratak u početno stanje

At $65 \% \mathrm{RH}$, creep/recovery curve related to the altitude of $800 \mathrm{~m}$ was formed in a higher level and curves related to the altitudes of $400 \mathrm{~m}$ and $1100 \mathrm{~m}$ were formed in a lower level, so that curves of these two classes of altitude almost overlap (Fig. 3a). At 95 $\% \mathrm{RH}$, the highest and lowest curves of creep/recovery were observed at altitudes of $800 \mathrm{~m}$ and $400 \mathrm{~m}$, respectively (Fig. 3b). Considering the effects of MOE and MOR on creep behavior of materials (Kaboorani et al., 2013), placing the creep/recovery curves of hornbeam wood samples resulting from the altitude of $800 \mathrm{~m}$ in an upper level can be due to the deficiency of bending properties at this altitude. Also, placing the curve of the altitude of $400 \mathrm{~m}$ in a lower level can be due to the increase of the MOE and MOR at this altitude.

At $65 \% \mathrm{RH}$, equilibrium moisture content (EMC) of samples at altitudes of 400, 800 and $1100 \mathrm{~m}$

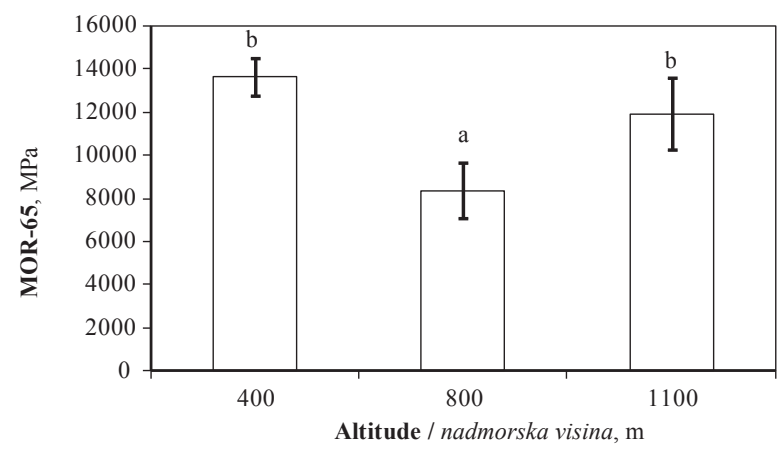

Figure 2 Hornbeam wood bending properties at three altitudes (95\% RH)

Slika 2. Svojstva drva graba pri savijanju za uzorke s tri nadmorske visine (95\% RH) 


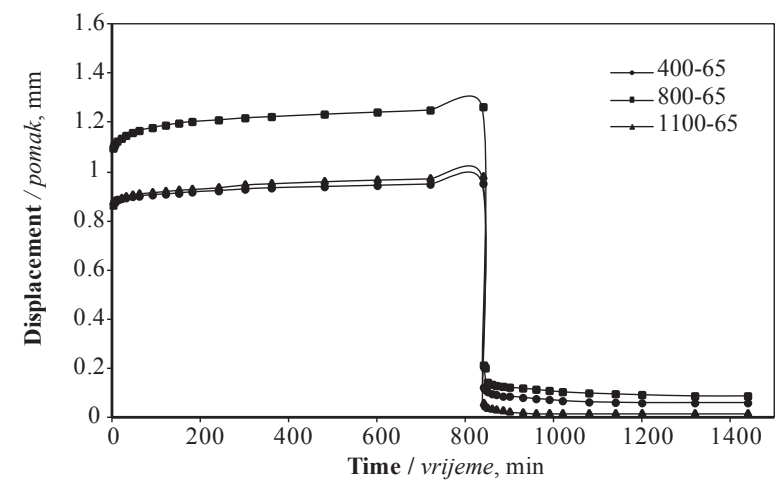

(a)

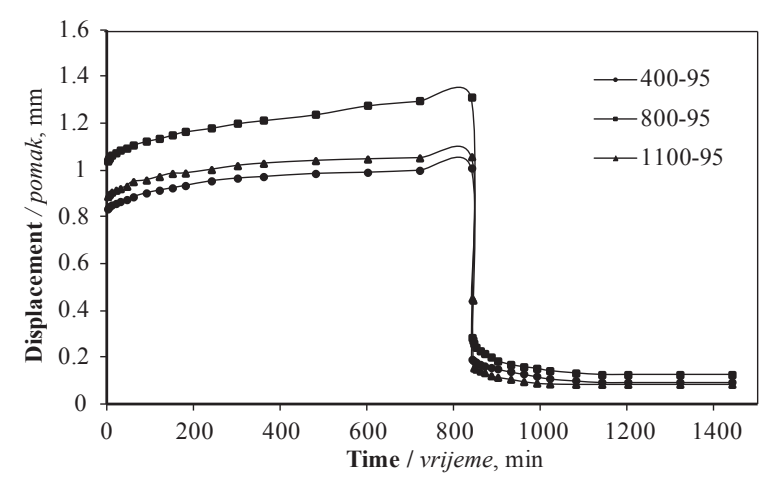

(b)

Figure 3 Creep/Recovery curves of hornbeam wood samples at different altitudes at (a) $65 \%$ and (b) $95 \%$ RH

Slika 3. Krivulje puzanja/oporavka uzoraka drva graba sa staništa na različitim nadmorskim visinama kondicioniranih pri: a) $65 \% \mathrm{RH}$ i b) $95 \% \mathrm{RH}$

was $30 \%, 30 \%$ and $29 \%$, respectively. ANOVA results indicated that altitude had a significant effect only on creep coefficient, while this factor had no significant effect on immediate displacement, maximum displacement, immediate return, permanent displacement and percentage of return (Table 3). According to Duncan's test, the average creep coefficient obtained from the altitude of $800 \mathrm{~m}$ and $1100 \mathrm{~m}$ was classified in one group, and the results obtained from the altitude of 400 $\mathrm{m}$ were classified in another group. The maximum average immediate displacement, maximum displacement, immediate return and permanent displacement and creep coefficient were observed at the altitude of $800 \mathrm{~m}$ and the maximum average return percentage was observed at the altitude of $1100 \mathrm{~m}$.

At $95 \%$ RH, EMC of samples at altitudes of 400 $\mathrm{m}, 800 \mathrm{~m}$ and $1100 \mathrm{~m}$ were $34 \%, 35 \%$ and $33 \%$, respectively. ANOVA results indicated that the effect of altitude on immediate displacement, maximum displacement, immediate return permanent displacement and percentage of return and creep coefficient was not significant. The maximum average immediate displacement, maximum displacement, permanent displacement and creep coefficient were observed at the altitude of $800 \mathrm{~m}$ and the maximum average immediate return and percentage of return were observed at the altitude of $1100 \mathrm{~m}$ (Table 4).

\subsection{Relationship between wood properties and immediate creep and maximum creep \\ 3.4. Odnos između svojstava drva s neposrednim puzanjem i s maksimalnim puzanjem}

Pearson's correlation results indicated that there was no relationship between fibers dimensions, density and bending properties and immediate and maximum displacement at $95 \% \mathrm{RH}$. At $65 \% \mathrm{RH}$, MOE had a significantly reverse relationship with immediate and maximum creep. A negative and significant relationship was also observed between densities and maximum displacement (Table 5).

Table 3 Values of hornbeam creep displacement at three altitudes $(65 \% \mathrm{RH})$

Tablica 3. Veličine pomaka pri puzanju uzoraka drva graba sa staništa na različitim nadmorskim visinama $(65 \% \mathrm{RH})$

\begin{tabular}{|c|c|c|c|c|c|c|c|c|}
\hline $\begin{array}{c}\text { Altitude } \\
\text { Nadmorska visina } \\
\mathrm{m}\end{array}$ & $\begin{array}{c}\text { RH } \\
\%\end{array}$ & $\begin{array}{c}\text { EMC } \\
\%\end{array}$ & $\begin{array}{l}\mathbf{I D}^{\mathbf{a}} \\
\mathrm{mm}\end{array}$ & $\begin{array}{c}\mathbf{M D}^{\mathbf{b}} \\
\mathrm{mm}\end{array}$ & $\begin{array}{l}\mathbf{I R}^{\mathbf{c}} \\
\mathrm{mm}\end{array}$ & $\begin{array}{l}\mathbf{P D}^{\mathbf{d}} \\
\mathrm{mm}\end{array}$ & $\mathbf{R P}^{\mathbf{e}}$ & $\mathrm{CC}^{\mathrm{f}}$ \\
\hline 400 & \multirow{3}{*}{65} & 30 & 0.86 & 0.95 & 0.12 & 0.05 & 84.61 & $1.097^{\mathrm{a}}$ \\
\hline 800 & & 30 & 1.09 & 1.26 & 0.21 & 0.08 & 93.02 & $1.15^{\mathrm{b}}$ \\
\hline 1100 & & 29 & 0.86 & 0.98 & 0.06 & 0.01 & 98.18 & $1.13^{\mathrm{b}}$ \\
\hline & $3.532^{\mathrm{ns}}$ & $4.420^{\mathrm{ns}}$ & $4.848^{\mathrm{ns}}$ & $0.985^{\mathrm{ns}}$ & $1.591^{\mathrm{ns}}$ & $20.069^{*}$ \\
\hline
\end{tabular}

a - Immediate displacement / neposredni pomak; b - Maximum displacement / najveći pomak; c - Immediate return / neposredni povratak, $\mathrm{d}$ Permanent displacement / trajni pomak; e - Return percentage / postotak povratka, f - Creep coefficient / koeficijent puzanja; * - Significant at $5 \%$ level / signifikantno na razini $5 \%$;* - Significant at $1 \%$ level / signifikantno na razini $1 \%$; ns - not significant / nije signifikantno

Table 4 Values of hornbeam creep displacement at three altitudes (95\% RH)

Tablica 4. Veličine pomaka pri puzanja uzoraka od drva graba sa staništa na različitim nadmorskim visinama $(95 \% \mathrm{RH})$

\begin{tabular}{|c|c|c|c|c|c|c|c|c|}
\hline $\begin{array}{c}\text { Altitude } \\
\text { Nadmorska visina } \\
\mathrm{m}\end{array}$ & $\begin{array}{c}\mathbf{R H} \\
\%\end{array}$ & $\begin{array}{c}\text { EMC } \\
\%\end{array}$ & $\begin{array}{l}\mathbf{I D}^{\mathbf{a}} \\
\mathrm{mm}\end{array}$ & $\begin{array}{c}\mathbf{M D}^{\mathbf{b}} \\
\mathrm{mm}\end{array}$ & $\begin{array}{l}\mathbf{I R}^{\mathbf{c}} \\
\mathrm{mm}\end{array}$ & $\begin{array}{l}\mathbf{P D}^{\mathbf{d}} \\
\mathrm{mm}\end{array}$ & $\mathbf{R} \mathbf{P}^{\mathbf{e}}$ & $\mathrm{CC}^{\mathrm{f}}$ \\
\hline 400 & \multirow{3}{*}{95} & 34 & 0.38 & 1 & 0.18 & 0.09 & 91.53 & 1.20 \\
\hline 800 & & 35 & 1.02 & 1.31 & 0.28 & 0.12 & 91.08 & 1.25 \\
\hline 1100 & & 33 & 0.88 & 1.055 & 0.24 & 0.08 & 92.58 & 1.19 \\
\hline \multicolumn{3}{|c|}{$\mathrm{F}$} & $1.831^{\mathrm{ns}}$ & $1.727^{\mathrm{ns}}$ & $0.572^{\mathrm{ns}}$ & $0.184^{\mathrm{ns}}$ & $0.035^{\mathrm{ns}}$ & $0.953^{\text {ns }}$ \\
\hline
\end{tabular}

a - Immediate displacement / neposredni pomak; b - Maximum displacement / najveći pomak; c - Immediate return / neposredni povratak, $\mathrm{d}$ Permanent displacement / trajni pomak; e - Return percentage / postotak povratka, f - Creep coefficient / koeficijent puzanja; ns - not significant I nije signifikantno 
Table 5 Relationship between wood properties and immediate and maximum creep of hornbeam wood at two levels of RH $65 \%$ and $90 \%$

Tablica 5. Odnos između svojstava drva s neposrednim i s maksimalnim puzanjem za uzorke od drva graba kondicionirane pri 65 i $95 \%$ relativne vlažnosti zraka

\begin{tabular}{|c|c|c|c|c|c|c|c|c|}
\hline $\begin{array}{c}\text { RH } \\
\text { Relativna } \\
\text { vlažnost } \\
\text { zraka } \\
\%\end{array}$ & $\begin{array}{c}\text { Creep } \\
\text { Puzanje } \\
\mathrm{mm}\end{array}$ & MOE & MOR & $\begin{array}{c}\text { Dry } \\
\text { density } \\
\text { Gustoća } \\
\text { suhogdrva } \\
\mathrm{kg} / \mathrm{m}^{3}\end{array}$ & $\begin{array}{c}\text { Lumen } \\
\text { diameter } \\
\text { Promjer } \\
\text { lumena } \\
\mu \mathrm{m}\end{array}$ & $\begin{array}{c}\text { Cell wall } \\
\text { thickness } \\
\text { Debljina stanične } \\
\text { stijenke } \\
\mu \mathrm{m}\end{array}$ & $\begin{array}{c}\text { Fiber } \\
\text { length } \\
\text { Duljina } \\
\text { vlakanaca } \\
\mu \mathrm{m}\end{array}$ & $\begin{array}{c}\text { Fiber } \\
\text { diameter } \\
\text { Promjer } \\
\text { vlakanaca } \\
\mu \mathrm{m}\end{array}$ \\
\hline 65 & $\mathrm{I}^{\mathrm{a}}$ & $-0.679^{*}$ & -0.589 & -0.643 & 0.490 & -0.473 & 0.405 & -0.215 \\
& $\mathrm{M}^{\mathrm{b}}$ & $-0.718^{*}$ & -0.662 & $-0.700^{*}$ & 0.461 & -0.439 & 0.385 & -0.269 \\
\hline 95 & $\mathrm{I}$ & -0.481 & -0.614 & -0.635 & 0.249 & 0.017 & 0.354 & -0.235 \\
\hline
\end{tabular}

a - Immediate / neposredno; b - Maximum / maksimalno; * - Significant at $5 \%$ level / signifikantno na razini $5 \%$

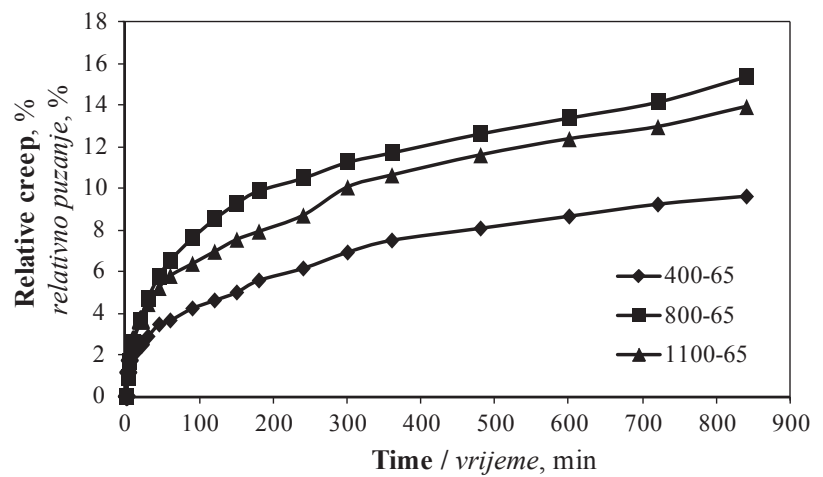

(a)

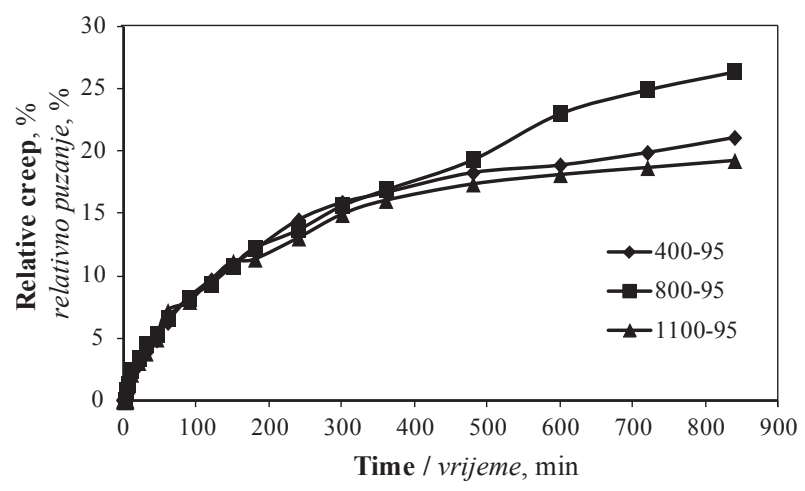

(b)

Figure 4 The effect of altitude on relative creep at $65 \%$ (a) and $95 \% \mathrm{RH}$ (b)

Slika 4. Utjecaj nadmorske visine staništa na relativno puzanje uzoraka drva graba kondicioniranih pri: a) $65 \%$ RH i b) $95 \%$ $\mathrm{RH}$

\subsection{Relative creep}

\subsection{Relativno puzanje}

At $65 \%$ RH during loading, the highest and lowest curves of relative creep at altitudes of $800 \mathrm{~m}$ and $400 \mathrm{~m}$ were observed (Fig. 4a). At $95 \%$ RH until 480 minutes, the percentage of relative creep at each of the three altitudes showed small differences. From this time onwards, the maximum value of relative creep was observed at the altitude of $800 \mathrm{~m}$, and the minimum value of relative creep was observed at the altitude of $1100 \mathrm{~m}$ (Fig. 4b).

Figure 5 shows the interactional effect of the three altitude classes at two levels of RH (65\% and 95

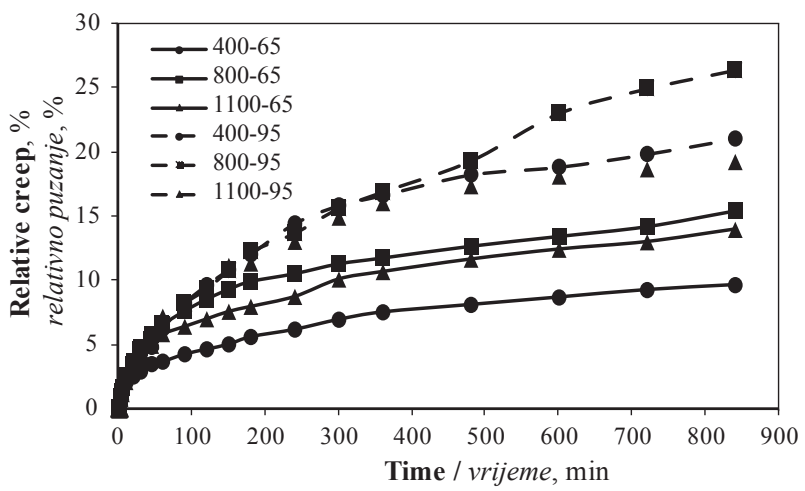

Figure 5 Interaction effects of altitudes and $\mathrm{RH}$ on relative creep in hornbeam wood

Slika 5. Interakcija utjecaja nadmorske visine staništa i relativne vlažnosti zraka pri kondicioniranju uzoraka na relativno puzanje drva graba
$\%$ ) on relative creep. Results indicated that curves of relative creep at $95 \% \mathrm{RH}$, related to each of the three altitudes, were higher than relative creep curves at 65 $\% \mathrm{RH}$.

\subsection{Creep modulus}

3.6. Modul puzanja

At two levels of RH (65\% and $95 \%$ ) all the time, the highest and the lowest curves of creep modulus were observed at the altitude of $400 \mathrm{~m}$ and $800 \mathrm{~m}$, respectively (Fig. 6a and b). Figure 7 shows the interaction effect of three altitude classes at RH of $65 \%$ and $95 \%$ on relative creep. The curves of creep modulus obtained at $65 \% \mathrm{RH}$ were above the curves of this parameter at $95 \% \mathrm{RH}$.

\subsection{Creep factor \\ 3.7. Faktor puzanja}

At $65 \%$ RH during loading, the highest and the lowest curves of creep factor were observed at the altitude of $800 \mathrm{~m}$ and $400 \mathrm{~m}$, respectively (Fig. 8a). At 95 $\% \mathrm{RH}$, until 480 minutes, creep factor curves in each of the three altitude classes showed small differences between each other and from this time onwards, the highest and the lowest curves were observed at the altitude of $800 \mathrm{~m}$ and $1100 \mathrm{~m}$, respectively (Fig. 8b).

Figure 9 shows the interactional effect of the three altitude classes and two levels of RH (65\% and $95 \%$ ) on creep factor. At $95 \% \mathrm{RH}$, curves of creep factor were placed the same as relative creep for each of the three altitude levels, upper than at $65 \% \mathrm{RH}$. At 


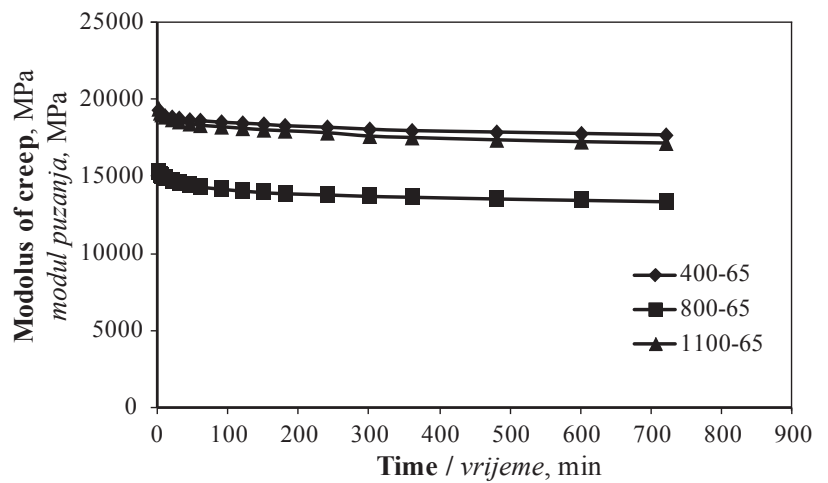

(a)

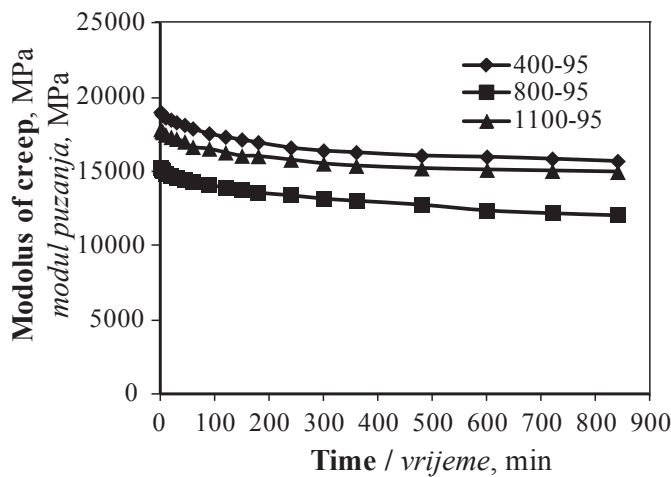

(b)

Figure 6 The effect of altitude on creep modulus at $65 \%$ (a) and $95 \%$ RH (b)

Slika 6. Utjecaj nadmorske visine staništa na modul puzanja uzoraka drva kondicioniranih pri: a) $65 \%$ RH i b) $95 \%$ RH

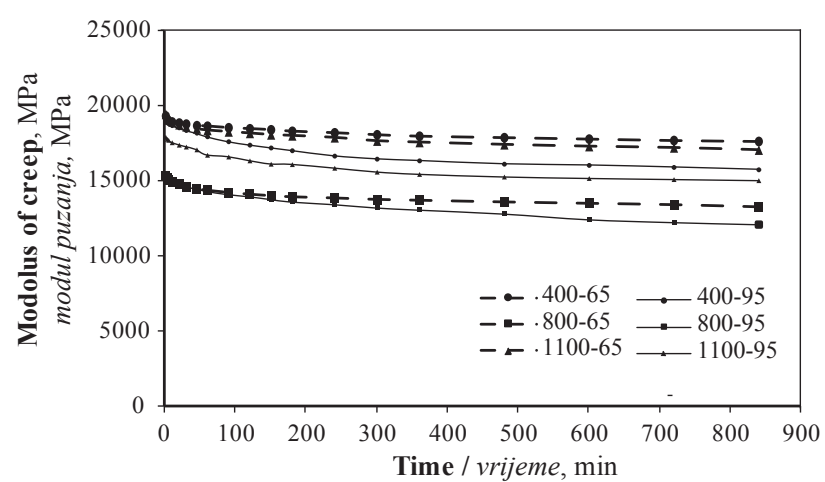

Figure 7 Interaction effects of altitudes and RH on creep modulus in hornbeam wood

Slika 7. Interakcija utjecaja nadmorske visine staništa i relativne vlažnosti zraka pri kondicioniranju uzoraka na modul puzanja drva graba

$95 \% \mathrm{RH}$, the highest curve was observed at the altitude of $800 \mathrm{~m}$ and at $65 \% \mathrm{RH}$, the lowest curve was observed at the altitude of $400 \mathrm{~m}$.

At two levels of RH (65\% and $95 \%)$, the relative creep and creep factor increase at the altitude of $800 \mathrm{~m}$, due to a lower value of MOE at this altitude, because there is an inverse relationship between immediate creep and maximum creep and MOE (Taniquichi and Ando 2010; Table 5). At the two levels of RH (65\% and $95 \%$ ), the lack of significance related to MOE at two altitudes, $400 \mathrm{~m}$ and $1100 \mathrm{~m}$, (Fig. 1 and 2) caused a little change in the procedure of measuring the relative creep and creep factor, as the least relative creep was observed at the altitude of $400 \mathrm{~m}$ and creep factor at the altitude of $1100 \mathrm{~m}$. There is, also, an inverse relationship between creep modulus and relative creep and creep factor, and for this reason maximum creep modulus was observed at the in altitude of $400 \mathrm{~m}$ for both levels of RH (65\% and $95 \%$ ). Relative creep and creep factor were higher at $95 \% \mathrm{RH}$ than at $65 \%$ $\mathrm{RH}$, which is compatible with the results of Van de kuilen research (1999).

Besides moisture, numerous factors affect the creep behavior of wood in the same way as load, microfibril angle (MFA) and temperature. Kojima and Yamamoto (2004) and Dong et al., (2010) reported that the increasing of MFA causes the decreasing of mechanical resistances and increasing of creep in wood.

\subsection{Fitting parabolic equations and curves to creep behavior of samples under study}

3.8. Prilagođivanje parabolične jednadžbe i krivulje ponašanju analiziranih uzoraka pri puzanju

At the two levels of RH (65\% and $95 \%$ ), two samples of empirical behavior compatible with treatments at the altitude of $400 \mathrm{~m}$ have been shown (Fig. 10). Having the value of $a$ and $m$ by plotting the related graphs and based on equation 4 , parabolic equations can be obtained for each sample.

Najafi and Kazemi Najafi (2009) reported that strain creep can be predicted for different times of loading and by parabolic equation. Calculated values

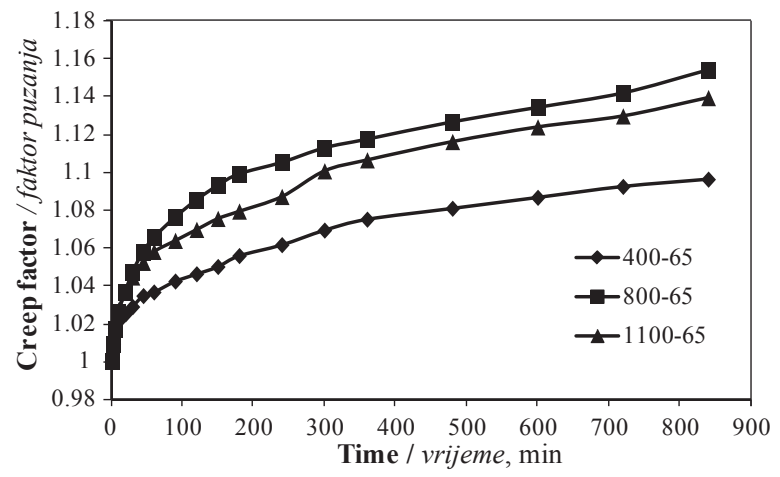

(a)

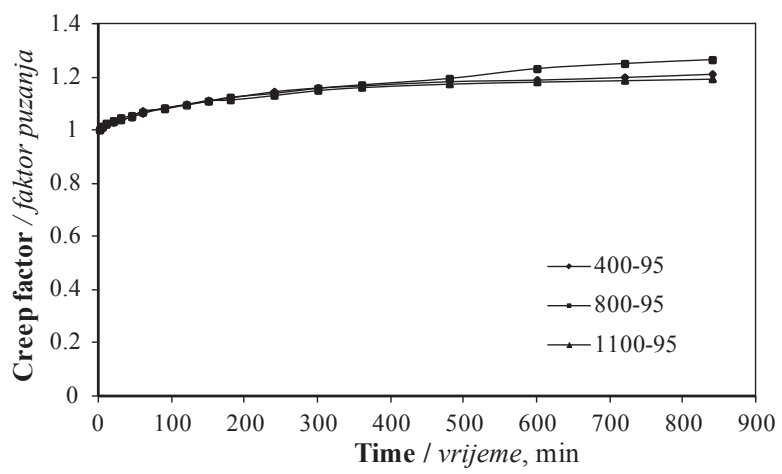

(b)

Figure 8 Effect of altitude on creep factor at $65 \%$ (a) and $95 \%$ RH (b)

Slika 8. Utjecaj nadmorske visine staništa na modul puzanja uzoraka drva graba kondicioniranih pri: a) $65 \%$ RH i b) $95 \%$ RH 


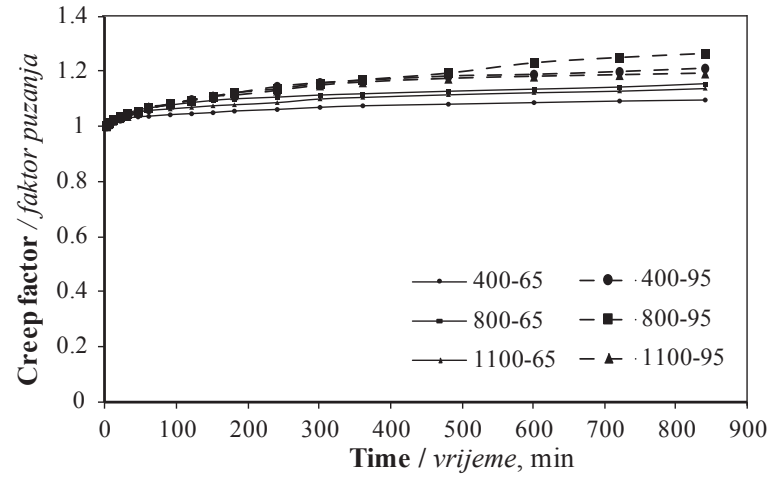

Figure 9 Interaction effects between altitudes and $\mathrm{RH}$ on creep factor in hornbeam wood

Slika 9. Interakcija utjecaja nadmorske visine staništa i relativne vlažnosti zraka pri kondicioniranju uzoraka na faktor puzanja drva graba

of $m, a$ and parabolic equations of all treatments are shown in Table 6. Based on the results it can be concluded that creep behavior of studied samples follows the power law proposed by Findley et al. (1989).

\section{CONCLUSION}

\section{ZAKLJUČAK}

1. The maximum density and cell wall thickness were present in samples from the altitude of $400 \mathrm{~m}$, the highest fiber length was detected at the altitude of 1100 $\mathrm{m}$ and the largest fiber diameter and lumen diameter were observed at the altitude of $800 \mathrm{~m}$.

2. At $65 \%$ and $95 \% \mathrm{RH}$, the maximum and the minimum amounts of MOE and MOR were observed at the altitude of $400 \mathrm{~m}$ and $800 \mathrm{~m}$, respectively.
3. At $65 \%$ and $95 \% \mathrm{RH}$, the maximum average immediate displacement, maximum displacement, permanent displacement and creep coefficient were observed at the altitude of $800 \mathrm{~m}$. Also the range of return creep was higher at $95 \% \mathrm{RH}$ than at $65 \% \mathrm{RH}$.

4. At $95 \% \mathrm{RH}$, there was no relationship of fiber size, density and bending properties with immediate displacement and maximum displacement, while at 65 $\% \mathrm{RH}, \mathrm{MOE}$ showed a reverse and significant relationship with immediate creep and maximum creep. Also, a negative and significant relationship was observed between oven-dry density and maximum displacement.

5. At $65 \%$ and $95 \% \mathrm{RH}$, the maximum values of relative creep and creep factor were observed at the altitude of $800 \mathrm{~m}$ and the maximum and minimum creep modulus at the altitude of $400 \mathrm{~m}$ and $800 \mathrm{~m}$, respectively.

6. The results of this research indicate that the use of hornbeam wood harvested at the altitude of $800 \mathrm{~m}$ is not recommended in applications under high bending forces, while wood harvested at altitudes of 400 and $1100 \mathrm{~m}$ is suitable.

\section{REFERENCES}

6. LITERATURA

1. Armstrong, L. D.; Kingston, R. S. T., 1960: Effect of moisture changes on creep in wood. Nature, 185 (4718): 862-863. http://dx.doi.org/10.1038/185862c0.

2. Armstrong, L. D.; Christensen, G. N., 1961: Influence of moisture changes on deformation of wood under stress. Nature, 191 (4791): 869-870. https://doi.org/10.1038/191869a0.

Table 6 Calculated values of $m$ and $a$ in parabolic equation Tablica 6. Izračunane vrijednosti $m$ i $a$ u paraboličnoj jednadžbi

\begin{tabular}{|c|c|c|c|c|c|c|}
\hline $\begin{array}{c}\text { Altitude } \\
\text { Nadmorska visina } \\
\mathrm{m}\end{array}$ & $\begin{array}{c}\mathbf{R H} \\
\%\end{array}$ & $m$ & $a$ & $\mu_{0}$ & $\mu_{0}+a t^{m}$ & $R^{2}$ \\
\hline 400 & \multirow{3}{*}{65} & 0.35 & 0.007 & 0.86 & $0.86+0.007 \cdot t^{0.35}$ & 0.99 \\
\hline 800 & & 0.45 & 0.009 & 1.09 & $1.09+0.009 \cdot t^{0.45}$ & 0.95 \\
\hline 1100 & & 0.38 & 0.009 & 0.86 & $0.86+0.009 \cdot t^{0.38}$ & 0.98 \\
\hline 400 & \multirow{3}{*}{95} & 0.58 & 0.004 & 0.83 & $0.83+0.004 \cdot t^{0.58}$ & 0.98 \\
\hline 800 & & 0.59 & 0.005 & 1.03 & $1.03+0.005 \cdot t^{0.59}$ & 0.99 \\
\hline 1100 & & 0.57 & 0.004 & 0.88 & $0.88+0.004 \cdot t^{0.57}$ & 0.97 \\
\hline
\end{tabular}

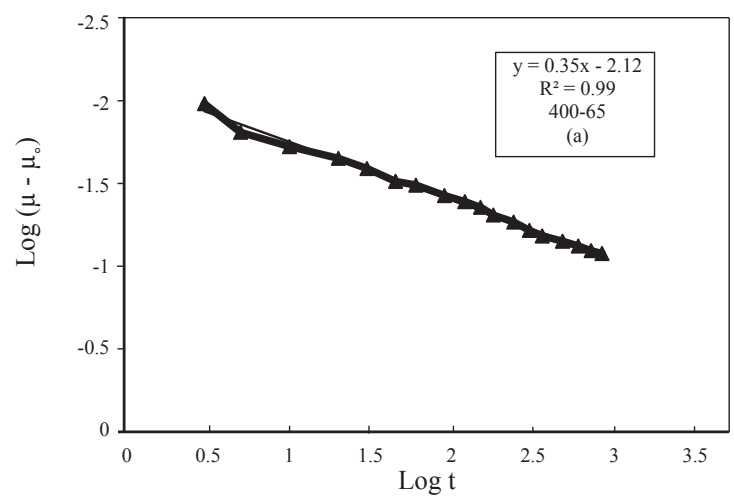

(a)

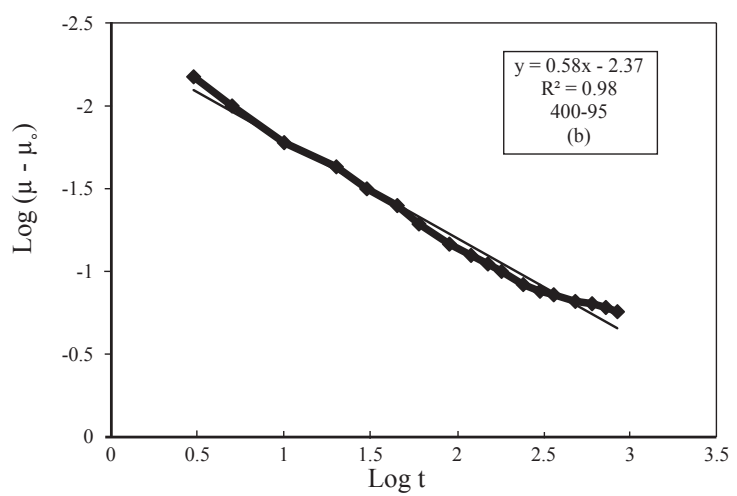

(b)

Figure 10 Creep behavior fitting plots for two samples at altitude of $400 \mathrm{~m}$ at $65 \%$ (a) and $95 \% \mathrm{RH}$ (b)

Slika 10. Prikaz prilagođenih krivulja koje pokazuju puzanje drva za uzorke s nadmorske visine $400 \mathrm{~m}$ kondicionirane pri: a) $65 \% \mathrm{RH}, \mathrm{b}) 95 \% \mathrm{RH}$ 
3. Armstrong, L. D.; Kingston, R. S. T., 1962: Effect of moisture content changes on the deformation of wood under stress. Aust J Appl Sci, 13 (4): 257-276.

4. Armstrong, L. D., 1972: Deformation of wood in compression during moisture movement. Wood Science, 5 (2): 81-86.

5. Bazant, Z. P.; Meiri, S., 1985: Measurements of compression creep of wood at humidity changes. Wood science and Technology, 19 (2): 179-182.

https://doi.org/10.1007/BF00353079.

6. Boding, J.; Jayne, B., 1993: The mechanics of wood and wood composites. Krieger publishing company, Malabar Florida, USA.

7. Charifo Ali, A., 2011: Physical-Mechanical properties and natural durability of lesser used wood species from Mozambique. Doctoral thesis Swedish university of agricultural sciences Uppsala.

8. Chen, T. Y.; Lin, J. S., 1997: Creep behaviour of commercial wood based boar under long-term loading at room conditions in Taiwan. European journal of wood and wood products, 55 (6): 371-376. https://doi.org/10.1007/s001070050249.

9. Christopher, J.; Hogan; Karl, J; Niklas, 2004: Temperature and water content effects on the viscoelastic behaviour of Tilia Americana (Tiliaceae) sapwood. Trees 18(3): 339-345. https://doi.org/10.1007/s00468-003-0311-x.

10. Dong, F.; Olsson, A. M.; Salmen, L., 2010: Fiber morphological effects on mechano-sorptive creep. Wood Science and Technology 44(3): 475-483. http://dx.doi. org/10.1007/s00226-009-0300-3.

11. Findley, W. N.; Lai, J. S.; Onaran, K., 1989: Creep and relaxation of nonlinear viscoelastic materials: with an introduction to linear viscoelasticity. Dover publications, Inc, New York.

12. Fridley, K. J., 1992a: Design for creep in wood structures. Forest products journal, Forest products research society, 42 (3): 23-28.

13. Fridley, K. J., 1992b: Creep-rupture behaviour of wood. Department of forestry and natural resources agricultural experiment station, Bulletin No. 637. Purdue University.

14. Hanhijarvi, A.; Hunt, D., 1998: Experimental indication of interaction between viscoelastic and mechano-sorptive creep. Wood Science and Technology, 32 (1): 57-70. https://doi.org/10.1007/BF00702560.

15. Ishimaru, Y.; Oshima, K.; Iida, I., 2001: Changes in the mechanical properties of wood during a period of moisture conditioning. Journal of Wood Science, 47 (4): 254261. https://doi.org/10.1007/BF00766710.

16. Kaboorani, A., Blanchet, P.; Laghdir, A., 2013: A rapid method to assess viscoelastic and mechano-sorptive creep in wood. Wood and fiber science, 45 (4): 370-382.

17. Kaboorani, A.; Blanchet, P., 2014: Determining the linear viscoelastic region of Sugar Maple wood by dynamic mechanical analysis. Bioresources, 9 (3): 4392-4409. https://doi.org/10.15376/biores.9.3.4392-4409.

18. Kiaei, M., 2012: Effect of site and elevation on wood density and shrinkage and their relationships in Carpinus betuluse. For. Stud. China, 14 (3): 229-234. http://dx.doi.org/10.1007/s11632-012-0310-3.

19. Kiaei, M., 2013: Effect of cultivation methods on wood static bending properties in Alnus Glutinosa. Drvna industrija, 64 (4): 265-271. http://dx.doi.org/10.5552/drind.2013.1240.

20. Kobbe, R. G., 2005: Creep behaviour of a wood-polypropylene composite. M.Sc. Thesis, Department of Civil and Environmental Engineering, Washington State University, USA.
21. Koga, S.; Zhang, Y., 2002: Relationships between wood density and annual growth rate components in balsam fir (Abies balsamea). Wood and Fiber Science, 34 (1): 146157.

22. Kojima, Y.; Yamamoto, H., 2004: Effect of microfibril angle on the longitudinal tensile creep behaviour of wood. Journal of Wood Science, 50 (4): 301-306. http://dx.doi.org/10.1007/s10086-003-0565-3.

23. Koubaa, A.; Zhang, S.Y.; Isabel, N.; Beaulieu, J.; Bousquet, J., 2000: Phenotypic correlations between juvenilemature wood density and growth in black Spruce. Wood and Fiber Science, 32 (1): 61-71.

24. Kowalski, S. J.; Kowal, M., 1998: Physical relation for wood at variable humidity. Transport in Porous Media, 31(3): 331-346. https://doi.org/10.1023/A:1006546701285.

25. Liu, T., 1993: Creep of wood under large span of loads in constant and varying environments. Holz als Roh- und werkstoff, 51 (6): 400-405. https://doi.org/10.1007/BF02628237.

26. Makhmalbaf, N.; Khademi-Eslam, H.; Hemmasi, A. H.; Bakhshi, R., 2007: An investigation on the relationship between stem size and longitudinal growth strains in hornbeam species (Carpinus betuluse). Ph. D. Thesis, Science and Research Branch, Islamic Azad University, Tehran, Iran.

27. Najafi, A.; Kazemi Najafi, S., 2009: Effect of load levels and plastic type on creep behaviour of wood sawdust/ HDPE composites. Journal of Reinforced Plastics and Composites 28(21): 2645-2653. http://dx.doi.org/10.1177/0731684408093320.

28. Nakano, T., 1999: Analysis of creep of wood during water adsorption based on the excitation response theory. Journal of Wood Science, 45 (1): 19-23.

29. Taniguchi, Y.; Ando, K., 2010: Time dependence of Poisson's effect in wood: Volume change during uniaxial tensile creep. Journal of Wood Science 56(2): 100-106. http://dx.doi.org/10.1007/s10086-009-1070-0.

30. Treacy, M.; Evertsen, J.; Dhubha' in, A., 2000: A comparison of mechanical and physical wood properties of range of Sitka spruce (Picea Sithchensis) provenances. The national council for forest research and development (COFORD), Finland.

31. Van De Kuilen, J. W. G., 1999: Duration of load effects in timber joints. Bibliotheek Technische universitet, Delft university press, Netherlands.

32. Van Der Put, T. A. C. M., 1989: Deformation and damage processes in wood. Delft University Press, Delft, Netherlands, $154 \mathrm{pp}$.

33. Zhang, S. Y.; Zhong, Y., 1990: Effect of growth rate on specific gravity of East-Liaoning Oak (Quercus Liaotungensis) wood. Canadian Journal of Forest Resources, 21 (2): 255-260. https://doi.org/10.1139/x91-031.

34. Zhang, S. Y., 1997: Wood specific gravity-mechanical property relationship at species Level. Wood Science and Technology, 31 (3): 181-191. https://doi.org/10.1007/ BF00705884.

35. Zhang, W.; Tokumoto, M.; Takeda, T., 2007: Effect of temperature on mechano-sorptive creep of delignified wood. Journal of Wood Science, 53 (3): 187-191. http://dx.doi.org/10.1007/s10086-006-0858-4.

36. Zhu, J. Y.; Vahey, D. W.; Scott, C. T., 2008: Some observations of wood density and anatomical properties in a Douglas-Fir sample with suppressed growth. Wood and Fiber Science, 40 (2): 225-232.

37. Zobel, B. J.; Van Buijtenen, B., 1989: Wood variation, its causes and control. Springer Verlag, Berlin, Heidelberg, New York, 363 pp.

https://doi.org/10.1007/978-3-642-74069-5. 
38. Zobel, B. J.; Sprague, J. R., 1998: Juvenile wood in trees. Springer Verlag, New York. https://doi.org/10.1007/978-3-642-72126-7.

39. ***ASTM D 143-94., 2000: Standard methods of testing small clear specimens of timber. Annual Books of ASTM standards Des. ASTM D 143- 94, Vol-4.10. Philadelphia, PA.

40. ***ASTM D 6815-09., 2015: Standard specification for evaluation of duration of load and creep effects of wood and wood-based products.

41. ***ISO 3131, 1975: Wood - Determination of density for physical and mechanical tests.

\section{Corresponding address:}

Assoc. Prof. HABIBOLLAH KHADEMI ESLAM, Ph.D.

Department of Wood and Paper Science and Technology

Science and Research Branch

Islamic Azad University

Tehran, IRAN

e-mail: h-khademieslam@gmail.com 